\title{
HUBUNGAN ANTARA TINGKAT STRES DAN KECERDASAN EMOSI DENGAN PERILAKU BULLYING PADA REMAJA DI KOTA PONTIANAK
}

\author{
(The Correlation Between The Stress Level And Emotional Quotient With \\ Bullying Behavior In Adolescence At Pontianak City) \\ Cintyakarin Cikal Agustanadea*, Djoko Priyono**, Rara Anggraini*** \\ * Mahasiswi Prodi Keperawatan Fakultas Kedokteran Universitas Tanjungpura, Pontianak \\ ** Dosen Keperawatan Fakultas Kedokteran Universitas Tanjungpura, Pontianak \\ *** Dosen Keperawatan Fakultas Kedokteran Universitas Tanjungpura, Pontianak \\ Email : cintyakarinagistanadea@gmail.com
}

\begin{abstract}
ABSTRAK
Latar Belakang : Remaja merupakan masa dimana seseorang mengalami perubahan fisik, psikologi dan sosial. Perubahan yang dialami remaja dapat menyebabkan munculnya perilaku bullying akibat dari tingkat stres dan kecerdasan emosi yang dimiliki remaja.

Tujuan : Mengetahui hubungan antara tingkat stres dan kecerdasan emosi dengan perilaku bullying pada remaja di kota Pontianak

Metode : Desain penelitian ini berupa deskriptif analitik dengan pendekatan cross sectional. Tehnik sampling yang digunakan adalah probability sampling dengan jumlah sampel dalam penelitian ini sebanyak 354 pada siswa menengah atas negeri di Kota Pontianak. Instrumen yang digunakan berupa kuesioner Perceive Stress Scale (PSS), kuesioner Self-Report Emotional Intellegence Test (SSEIT), dan kuesioner Adolescent Peer Relations Instrument (APRI) seksi A. Analisis statistik menggunakan uji Spearman rank dengan nilai $\mathrm{p}<0,05$.

Hasil : Jenis kelamin terbanyak adalah perempuan sebanyak 58,8\%\% dengan suku terbanyak yaitu Melayu sebanyak 48,0\% dan agama terbanyak yaitu Islam sebanyak 83,3\%.Hasil uji statistik didapatkan nilai p pada tingkat stres dengan perilaku bullying $\mathrm{p}=0,290$ dan nilai $\mathrm{p}$ pada kecerdasan emosi dengan perilaku bullying $\mathrm{p}=0,627$.

Kesimpulan :Tidak ada hubungan antara tingkat stres dan kecerdasan emosi dengan perilaku bullying. Semakin ringan tingkat stres atau semakin tinggi kecerdasan emosi, tidak menutup kemungkinan seseorang melakukan bullying.
\end{abstract}

Kata Kunci : Tingkat Stres, Kecerdasan Emosi, Perilaku Bullying 


\begin{abstract}
Background : Adolescence is a period where a person experiences physical, psychological and social changes. Changes experianced can induce bullying behavior caused by the level of stress and emotional quotient possessed by adolescents.

Aim : To find out the correlation between stress level and emotional quotient with bullying behavior in adolescences at Pontianak.

Method : The design of this study is descriptive with cross sectional approach. The sampling technique used is probability sampling with the number of samples in this study as many as 354 in senior high schools in the city of Pontianak. The instruments used were the Perceive Stress Scale (PSS) questionnaire, Self-Report Emotional Intelligence Test (SSEIT) questionnaire, and Adolescent Peer Relations Instrument (APRI) section A questionnaire.. Statistical analysis used the Spearman rank test with $p$ value $<0,005$.

Result : Most gender is a girl as much as 58.8\%, most tribes is Malay as much as $48.0 \%$ and most religions is Islam as much as $83.3 \%$. The result of Spearman test gets $p$ value of stress level with bullying behavior is $p=0,290$ and p value of emotional quotient with bullying behavior is $p=0,62$.

Conclusion :There is no correlation between stress level and emotional quotient with bullying behaviour. The lighter the stress level or the higher emotional quotient, does not rule out the possibility of someone bullying.
\end{abstract}

Keyword : : Stress Level, Emotional Quotient, Bullying Behavior

\section{PENDAHULUAN}

Masa remaja merupakan masa transisi dari masa anak-anak menuju dewasa dan merupakan bagian kehidupan yang penting dalam siklus perkembangan. ${ }^{19}$ Remaja merupakan masa peralihan dimana periode ini ditemukan berbagai perubahan terjadi baik perubahan hormonal, fisik, psikologis maupun sosial. Perubahan ini terjadi dengan sangat cepat dan terkadang tanpa disadari. ${ }^{7}$

World Health Organization (WHO) tahun 2014 menyatakan $18 \%$ dari penduduk di dunia atau sebanyak 1,2 milyar adalah remaja. ${ }^{16}$ Prevalensi remaja menurut hasil survei Penduduk Antar Sensus pada tahun 2015 terdapat 21.110.721 penduduk $15-19$ tahun. ${ }^{5}$ Umur masa remaja merupakan kategori penduduk usia sekolah. Jumlah penduduk remaja usia sekolah yang ada di Kalimantan Barat berdasarkan data dari Badan Pusat Statistik (2010) didapatkan hasil yaitu jumlah penduduk usia sekolah berusia 13 - 15 tahun berjumlah 263.232 jiwa dan penduduk usia sekolah berusia 15 - 18 tahun berjumlah 239.461 jiwa. $^{4}$

Pertumbuhan dan perkembangan remaja terdapat perbedaan karakteristik pada setiap individu yang mempengaruhi pada saat mulainya masa remaja sehingga pada masa remaja sering terlihat perubahan berupa kegelisahan, pertentangan, keinginan mencoba hal yang belum pernah diketahui, keinginan menjelajah alam sekitar, mengkhayal dan berfantasi, serta aktivitas berkelompok. $^{11}$ Pada remaja terjadi peningkatan alasan logis dan abstrak serta 
secara perkembangan emosional atau psikologis, anak remaja umumnya berjuang menuju kematangan dan kebebasan. ${ }^{2}$

Perkembangan emosional dan psikologis pada remaja dapat direfleksikan dengan melakukan kenakalan remaja seperti membantah orang tua, tindakan agresif kepada teman sebaya, perkembangan sikap asertif, kebahagiaan remaja dalam keadaan tertentu yang dialaminya dan peran gender serta salah satu bentuk dari kenakalan remaja adalah perilaku bullying. ${ }^{9}$ Bullying merupakan salah satu bentuk tindakan agresif dari seorang individu yang lebih berkuasa dapat berbentuk kekerasan fisik, verbal maupun sosial yang dilakukan dengan sengaja dan dalam periode tertentu. ${ }^{25}$ Berdasarkan data dari KPAI terdapat kasus yang banyak mengenai kekerasan atau bullying. Lingkungan sekolah merupakan tempat yang banyak ditemukan kejadian bullying sekitar $61-73 \%$ tindakan dalam bentuk kekerasan, pemerasan, mengancam dan mengambil barang. ${ }^{1}$

Perilaku bullying merupakan salah satu bentuk kenakalan remaja yang merupakan dampak dari stres dan kecerdasan emosi yang rendah. Perkembangan psikologis atau emosi remaja bersifat negatif dan temperamental. Oleh karena itu untuk mencapai kematangan emosi merupakan tugas perkembangan yang sangat sulit bagi remaja terutama pada masa remaja madya (pertengahan) yang memiliki tugas perkembangan utama yaitu mencari identitas diri. ${ }^{19}$ Upaya untuk mencapai kematangan emosi atau memilki perkembangan psikologis yang baik pada remaja diperlukan adanya kecerdasan emosi dan mengontrol stres.

Stres adalah sebuah keadaan dimana terdapat tuntunan non spesifik yang mengharuskan seseorang individu untuk melakukan suatu tindakan atau memberikan suatu respon. ${ }^{24}$ Menurut data Riset Kesehatan Dasar (Rikesdas) pada tahun 2013 prevalensi kejadian stres pada remaja di Indonesia meningkat dari tahun ketahun. Sebesar $(6,0 \%)$ masyarakat Indonesia yang berumur lebih dari 15 pada anak sekolah mengalami gangguan mental emosional berupa stres, kecemasan, dan depresi. ${ }^{15}$ Penyebab stres yang dialami oleh remaja yaitu penyesuaian terhadap lingkungan sosial yang dihadapi sehari - hari yang meliputi lingkungan keluarga termasuk suasana dan pola asuh yang diterapkan keluarga, lingkungan sekolah termasuk suasana sekolah dan lingkungan masyarakat termasuk sosial budaya. $^{23}$

Salah satu penyebab dari tindakan bullying adalah kecerdasan emosi rendah. Kecerdasan emosi adalah suatu kemampuan individu dalam memahami perasaan mengelola emosi dengan memberikan motivasi pada diri sendiri sehingga dapat mengatasi masalah dalam menyelesaikan tugas yang sulit atau hambatan dalam mencapai suatu tujuan tertentu. ${ }^{22}$ Kecerdasan emosi remaja khususnya pada madya berusia 15-18 tahun seringkali ditemukan remaja yang bingung dalam mencari identitas diri, tidak tahu harus memilih yang mana, memilih antara optimis atau pesimis dan sebagainya. ${ }^{19}$

Studi pendahuluan yang dilakukan pada Dinas Pendidikan dan Kebudayaan Provinsi Kalimantan Barat sebagaimana yang menangani mengenai Sekolah Menengah Atas (SMA) yang ada di Kalimantan Barat, didapatkan hasil bahwa terdapat 10 sekolah negeri tingkat SMA yang terdapat di Kota Pontianak yang memiliki 3092 siswa yang duduk di kelas X di Kota Pontianak.

Berdasarkan hasil studi pendahuluan yang telah dilakukan oleh peneliti di dua SMA Negeri yaitu di SMA Negeri 7 dan SMA Negeri 10 dengan mewawancarai 20 siswa yang duduk dikelas $\mathrm{X}$ pada tanggal 30 Desember 2018 didapatkan hasil terdapat 13 siswa yang mengatakan mengalami stres dengan masalah yang dihadapi sehari - hari. Terdapat remaja yang mengatakan stres 
bukan karena dari lingkungan sekolah tetapi ada masalah di rumah. Para siswa merasakan stres dengan kehidupan sekolah sehari - hari yang kebanyakan stres akibat banyaknya tugas yang diberikan dan masalah yang ada di lingkungan. Terdapat 15 dari 20 siswa mengatakan bahwa mengalami emosi yang tidak stabil. Sebagaian besar para remaja pada saat sekolah mengatakan bahwa mudah marah atau sensitif dan mudah terbawa emosi atau tidak dapat mengendalikan emosi.

Stres yang tinggi dan kecerdasan emosi yang rendah dapat memicu seseorang untuk melakukan tindakan bullying yang dapat merugikan seperti melakukan tindak kekerasan di lingkungan sekolah. Tercatat pada tanggal 30 Mei sampai 22 Juli 2018 terdapat 41 kasus anak pelaku kekerasan dan bullying di Indonesia yang disampaikan oleh Komisioner KPAI bidang pendidikan. ${ }^{30}$ Dampak pada remaja yang tidak dapat mengontrol psikologisnya dapat berupa timbulnya perilaku menarik diri, perilaku kekerasan, menggunakan obat terlarang, alkohol, tidur tidak teratur, dan dapat menangis tanpa alasan.6

Dengan banyaknya fenomena diatas sehingga perlu untuk diteliti penelitian dengan judul "Hubungan Tingkat Stres Dan Kecerdasan Emosi Dengan Perilaku Bullying Pada Remaja Di Kota Pontianak”.

\section{METODE}

Jenis penelitian ini adalah penelitian kuantitatif menggunakan desain penelitian deskriptif analitik dengan pendekatan cross sectional. Proses pengumpulan data yaitu pada tanggal 25 maret - 16 april 2019 yang dilakukan pada sepuluh Sekolah Menengah Atas (SMA) negeri di Kota Pontianak yaitu SMA negeri 1, SMA negeri 2, SMA negeri 3, SMA negeri 4, SMA negeri 5, SMA negeri 6, SMA negeri 7, SMA negeri 8, SMA negeri 9, dan SMA negeri 10. Jumlah responden yang digunakan sebanyak 354 responden. Teknik yang digunakan untuk pengambilan sampel adalah probability sampling dengan menggunakan simple random sampling. Instrumen yang digunakan pada penelitian ini yaitu kuesioner Perceive Stress Scale (PSS), kuesioner Self-Report Emotional Intellegence Test (SSEIT), dan kuesioner Adolescent Peer Relations Instrument (APRI) seksi A. Analisis data pada penelitian ini menggunakan analisis statistik komputer. pengolahan data yang telah terkumpul dilakukan dengan menggunakan frekuensi untuk analisis univariat, dan analisis bivariat menggunakan uji Spearman rank untuk melihat hubungan tingkat stress dan kecerdasan emosi dengan perilaku bullying.

\section{HASIL}

1. Analisis Univariat

Tabel. 1 Distribusi Frekuensi Responden Berdasarkan Jenis Kelamin, Suku dan Agama pada Remaja Di Kota Pontianak $(\mathrm{N}=354)$

\begin{tabular}{lcc}
\hline Karakteristik & F & \% \\
\hline JenisKelamin & 146 & 41,2 \\
Laki - Laki & 208 & 58,8 \\
Perempuannn & 170 & 48,0 \\
\hline Suku & 31 & 8,8 \\
Melayu & 78 & 22,0 \\
Dayak & 9 & 2,5 \\
Jawa & 12 & 3,4 \\
Sunda & 19 & 5,4 \\
Batak & 9 & 2,5 \\
Bugis & 17 & 4,8 \\
Madura & 1 & 0,3 \\
Tionghoa & 2 & 0,6 \\
Flores & 2 & 0,6 \\
Minang & 1 & 0,3 \\
Ambon & 3 & 0,8 \\
Aceh & & \\
Arab & 295 & 83,3 \\
\hline Agama & 33 & 9,3 \\
Islam & 24 & 6,8 \\
Katolik & 2 & 0,6 \\
Protestan & Budha &
\end{tabular}

Sumber: Data Primer (2019), telah diolah 
Hasil analisis pada tabel. 1 di atas menunjukkan bahwa karakteristik jenis kelamin terbanyak adalah perempuan yaitu $58,8 \%$, karakteristik suku terbanyak adalah Melayu yaitu 48,0 \%, karakteristik agama terbanyak adalah Islam yaitu $83,3 \%$.

Tabel. 2 Distribusi FrekuensiTingkat stres pada remaja SMA Negeri di Kota Pontiank $(\mathrm{N}=354)$

\begin{tabular}{lcc}
\multicolumn{1}{c}{ Tingkat stres } & f & \% \\
\hline Stres ringan & 44 & 12,4 \\
Stres sedang & 301 & 85,0 \\
Stres berat & 9 & 2,5 \\
\hline
\end{tabular}

Sumber: Data Primer (2019), telah diolah

Berdasarkan tabel. 2 di atas didapatkan bahwa tingkat stres yang paling banyak dialami oleh responden adalah tingkat stres sedang yaitu sebesar $85,0 \%$.

Tabel. 3 Distribusi Frekuensi Kecerdasan emosi pada remaja SMA Negeri di Kota Pontianak $(\mathrm{N}=354)$

\begin{tabular}{lcc}
\hline Kecerdasan Emosi & f & \% \\
\hline Tinggi & 44 & 12,4 \\
Sedang & 265 & 74,9 \\
Rendah & 45 & 12,7 \\
\hline
\end{tabular}

Sumber: Data Primer (2019), telah diolah

Berdasarkan tabel. 3 diatas didapatkan bahwa kecerdasan emosi yang paling banyak dimiliki oleh responden adalah kecerdasan emosi sedang yaitu sebesar 74,9\%.

Tabel. 4 Distribusi Frekuensi Perilaku bullying pada Remaja SMA Negeri di Kota Pontianak $(N=354)$

\begin{tabular}{lcc}
\hline \multicolumn{1}{c}{$\begin{array}{c}\text { Analisis Perilaku } \\
\quad \text { Bullying }\end{array}$} & f & \% \\
\hline Tidak pernah & 16 & 4,5 \\
Pernah & 338 & 95,5 \\
\hline
\end{tabular}

Sumber: Data Primer (2019), telah diolah

Berdasarkan tabel. 4 diatas didapatkan bahwa responden mayoritas pernah melakukan perilaku bullying yaitu sebesar $95,5 \%$.

\section{Analisis Bivariat}

Tabel. 5 Hubungan Tingkat Stres dengan Perilaku Bullying Pada Remaja Sekolah Menengah Atas di Kota Pontianak.

\begin{tabular}{|c|c|c|c|c|c|c|c|}
\hline & & & rilaku & ully & & & \\
\hline & & & hah & & $\begin{array}{l}\text { dak } \\
\text { nah }\end{array}$ & $\mathrm{R}$ & $\begin{array}{l}\text { val } \\
\text { ue }\end{array}$ \\
\hline & & $\mathrm{f}$ & $\%$ & f & $\%$ & & \\
\hline Tin- & Nor & 0 & 0 & 0 & 0 & - & 0,2 \\
\hline gkat & mal & & & & & 0,0 & 90 \\
\hline str- & & & & & & 56 & \\
\hline es & $\begin{array}{l}\text { Rin } \\
\text { gan }\end{array}$ & 43 & 97,7 & 1 & 2,3 & & \\
\hline & Sed & 287 & 95,3 & 14 & 4,66 & & \\
\hline & ang & & 4 & & & & \\
\hline & $\begin{array}{l}\text { Ber } \\
\text { at }\end{array}$ & 8 & 88,8 & 1 & 11,2 & & \\
\hline Tota & & 338 & 95,5 & 16 & 4,5 & & \\
\hline
\end{tabular}

Sumber: Data Primer (2019), telah diolah

Berdasarkan Tabel 4.5 diatas didapatkan bahwa dari hasil uji statistik spearman dengan total 354 responden menunjukan nilai $p=0,290$ yang berarti $p>0,05$.Nilai korelasi spearman sebesar -0,056 menunjukkan arah korelasi negatif dengan ekuatan korelasi sangat lemah. Dapat disimpulkan bahwa Ho diterima yang artinya tidak ada hubungan antara Tingkat Stres dengan Perilaku Bullying pada Remaja di Kota Pontianak.

Tabel. 6 Hubungan Kecerdasan Emosi dengan Perilaku Bullying Pada Remaja Sekolah Menengah Atas di Kota Pontianak. 


\begin{tabular}{|c|c|c|c|c|c|c|c|}
\hline & & \multicolumn{4}{|c|}{ Perilaku bullying } & \multirow[b]{2}{*}{$\mathrm{r}$} & \multirow{2}{*}{$\begin{array}{c}\mathrm{p} \\
\text { val } \\
\text { ue }\end{array}$} \\
\hline & & \multicolumn{2}{|c|}{ Pernah } & \multicolumn{2}{|c|}{$\begin{array}{c}\text { Tidak } \\
\text { Pernah }\end{array}$} & & \\
\hline & & $\mathrm{f}$ & $\%$ & $\mathrm{f}$ & $\%$ & & \\
\hline \multirow{4}{*}{$\begin{array}{l}\text { Ke- } \\
\text { erd- } \\
\text { asa- } \\
\mathrm{n} \\
\text { em- } \\
\text { osi }\end{array}$} & Tin & 42 & 95,4 & 2 & 4,55 & \multirow{4}{*}{$\begin{array}{l}- \\
0, \\
02 \\
6\end{array}$} & 0,6 \\
\hline & ggi & & 5 & & & & 27 \\
\hline & Sed & 254 & $\begin{array}{c}95,8 \\
4\end{array}$ & 11 & 4,16 & & \\
\hline & $\begin{array}{l}\text { Ren } \\
\text { dah }\end{array}$ & 42 & 93,3 & 3 & 6,7 & & \\
\hline Tota & & 338 & 95,5 & 16 & 4,5 & & \\
\hline
\end{tabular}

Sumber: Data Primer (2019), telah diolah

Berdasarkan Tabel. 6 diatas didapatkan bahwa dari hasil uji statistik spearman dengan total 354 responden menunjukan nilai $p=0,627$ yang berarti $p>0,05$. Nilai korelasi spearman sebesar -0,026 menunjukkan arah korelasi negatif dengan kekuatan korelasi sangat lemah. Dapat disimpulkan bahwa Ho diterima yang artinya tidak ada hubungan antara Kecerdasan Emosi dengan Perilaku Bullying pada Remaja di Kota Pontianak.

\section{PEMBAHASAN}

\section{Karakteristik Responden Berdasarkan Jenis Kelamin}

Hasil penelitian menunjukan bahwa jumlah responden paling banyak yaitu perempuan sebanyak 58,8\% sedangkan jumlah responden laki - laki sebnayak $41,2 \%$.

Menurut Brizendine dalam Nasrani dan Purnawati terdapat perbedaan antara jenis kelamin laki - laki dan perempuan dalam mengontrol stres. Perempuan memiliki sikap kewaspadaan yang negatif sehingga dapat menimbulkan stres, gelisah dan rasa takut sedangkan laki - laki dapat menganggap konflik dapat memberikan dorongan ke arah positif. $^{18}$
Hasil penelitian yang dilakukan oleh Yuliana dan Hidayati menunjukan bahwa ada hubungan antara jenis kelamin dan tingkat stres seseorang. Remaja perempuan memiliki sifat lebih sering memendam rasa atau memakai emosi sedangkan pada remaja laki - laki lebih mudah untuk meluapkan emosi pada dirinya. Jenis kelamin dapat mempengaruhi stres dikarenakan remaja perempuan lebih peka terhadap lingkungannya. ${ }^{34}$

Responden perempuan lebih banyak daripada laki - laki dikarenakan populasi siswa perempuan lebih banyak daripada siswa laki - laki di SMA negeri di Kota Pontianak. Responden perempuan lebih banyak sehingga dapat mempengaruhi hasil dari peneltian dikarenakan perempuan lebih peka dan menggunakan perasaan yang dapat menimbulkan stres pada remaja perempuan dibandingkan laki - laki. Perilaku bullying yang dilakukan laki - laki lebih mengarah melakaukan bullying verbal dan bullying fisik dengan memaki sesama teman laki laki maupun memaki teman perempuan sedangkan pada perempuan lebih menggunakan bullying verbal daripada bullying fisik seperti mengatai teman kelas, mengolok teman kelas.

\section{Karakteristik Responden Berdasarkan Suku}

Hasil penelitian ini terdapat 13 suku yang dimiliki responden. Suku responden yang termasuk banyak adalah Melayu yaitu 48,0 \% dan suku Jawa terdapat 22,0\%.

Adanya perbedaan suku atau etnis adalah salah satu aspek penting bagi seorang individu agar dapat hidup rukun dengan orang lain yang sangat beragam dan multikultur. Kegagalan mengakui adanya keberagaman ini dapat menimbulkan hal hal kesenjangan dalam kehidupan. Perbedaan suku dan budaya merupakan potensi tetapi hal ini dapat menjadi salah satu pemicu adanya bullying. ${ }^{26}$ 
Penelitian mengenai studi fenomenologi konteks budaya Jawa pada empati remaja didapatkan hasil bahwa terdapat budaya jawa mengenai masalah apapun keadaan yang sedang dihadapi oleh seseorang bukan salah satu penghambat seseorang berkomunikasi dengan orang lain. Keluarga jawa selalu berpegang pada nilai - nilai moral salah satunya mengenai nilai kepedulian saling menolong dan tidak mencelakai satu sama lain. $^{33}$

Penelitian yang mengenai kebudayaan Melayu dalam kehidupan muslim didapatakan hasil terdapat pengaruh terhadap orang melayu mengajarkan untuk saling menolong satu sama lain dan gotong royong. Budaya yang diajarkan secara tidak langsung membuat tingkah laku seseorang mengikuti budaya atau suku yang dimilkinya. ${ }^{3}$

Suku Melayu adalah mayoritas suku yang ada di Kalimantan Barat khususnya di Pontianak. Bahasa yang digunakan mayoritas remaja juga menggunakan bahasa Melayu dalam berkomunikasi sehari - hari. Berdasarkan hasil penelitian Yusriadi didapatkan bahwa penduduk Kalimantan Barat berkisar 40 - 50\% adalah berasal dari suku Melayu. ${ }^{35}$ Suku Jawa merupakan suku yang banyak ditemui dikarenakan adanya kedatangan para suku Jawa dari pulau Jawa bertujuan karena berpindah tugas seperti polisi atau tentara yang mendapat tugas di Kota Pontianak yang kemudian hidup dan membuat keluarga di Kota Pontianak. Berdasarkan hasil penelitian Haba didapatkan Provinsi Kalimantan Barat merupakan provinsi keempat terluas yang ada di Indonesia yang memiliki beragam suku baik suku asli maupun suku pendatang. ${ }^{10}$

Beragam suku yang dimiliki responden baik remaja laki - laki maupun perempuan tidak membedakan bergaul memandang suku. Remaja saling berbaur satu sama lain meskipun adanya perbedaan suku dan budaya. Remaja dapat beradaptasi dengan perbedaan suku yang ada di lingkungan sekitar

\section{Karakteristik Responden Berdasarkan Agama}

Hasil penelitian ini didapatkan sebagian besar agama yang dimiliki adalah Islam yaitu $83,3 \%$. Agama yang paling sedikit jumlahnya pada penelitian ini yaitu agama Budha yaitu $0,6 \%$.

Berdasarkan hasil penelitian dari Novitasari, Yusuf dan Ilfiandra mengenai spiritualitas pada remaja didapatkan hasil tidak terdapat perbedaan spiritualitas dari remaja laki - laki maupun perempuan. Pada saat mengalami masa - masa sulit, para remaja mencari jalan keluar dengan mencari Tuhan. Di Indonesia memiliki beberapa agama dan setiap masyarakat memiliki kebutuhan beribadah dan mempunyai hubungan batin terhadap Tuhan Yang Maha Esa. ${ }^{20}$

Penelitian yang dilakukan oleh Wewengkang dan Moordiningsih mengenai studi fenomelogi pengaruh islam dalam membangun empati remaja didapatkan hasil bahwa didalam agama Islam mengajarkan untuk selalu memiliki akhlak yang mulia dalam berkehidupan sehari - hari sesuai perintah Allah. Islam menuntut seseorang dapat saling memperhatikan satu sama lain, peduli dengan orang lain, saling membantu dan dapat membangun tanggung jawab sosial yang dimiliki. ${ }^{33}$

Islam merupakan agama mayoritas yang ada di Kota Pontianak. Pada umunnya suku tebesar di Kalimantan Barat yaitu melayu identic dengan menganut agama Islam. Bedasarkan Data Statistik Kependudukan Kalimantan Barat tahun 2018 didapatkan sebanyak 1.657 .680 penduduk beragama Islam. ${ }^{8}$

Berdasarkan hasil penelitian ini, didapatakan mayoritas beragama islam dan terdapat agama lain seperti Kristen dan Budha. Adanya perbedaan keyakinan yang 
dimiliki oleh remaja tidak mempengaruhi remaja dalam melakukan aktifitas. Saat penelitian terdapat remaja muslim yang sedang mengaji di dalam kelas dan tidak ada remaja yang non muslim dikelas tersebut yang melarang remaja tersebut mengaji. Terdapat toleransi beragama yang tinggi di dalam kelas tersebut.

\section{Tingkat Stres Pada Remaja Sekolah Menengah Atas Negeri Di Kota Pontianak}

Hasil penelitian yang telah dilakukan dengan menggunakan kuesioner PSS didapatkan dari 354 responden tingkat stres yang paling banyak dialmi oleh remaja yaitu stres sedang sebesar $85,0 \%$.

Stres dapat dialami pada remaja akibat dari timbulnya perubahan besar terhadap persepsi yang dimiliki dan pengalaman yang dilalui. Stres dapat terjadi dikarenakan adanya rangsangan yang memicu stres baik dalam diri maupun dari lingkungan luar seperti keadaan emosi yang dialami atau adanya perubahan peran di dalam lingkungan keluarga maupun sosial. ${ }^{24}$

Remaja yang tidak dapat mengendalikan situasi memiliki peluang mengalami stres yang lebih besar. Semakin besar kendali yang dapat dimilki oleh remaja bahwa ia dapat melakukan sesuatu atau mengonrol diri, semakin kecil kemungkinan stres yang akan timbul. $^{6}$

Hasil penelitian yang dilakukan oleh Suci mengenai hubungan stres akademik dengan prestasi belajar pada Siswa SMA Negeri 1 Sawahlunto didapakan adanya tingkat stres dalam kategori tinggi yang dialami oleh siswa SMA Negeri 1 Sawahlunto. Stres dalam kategori tinggi ini dapat terjadi dikarenakan siswa belum sepenuhnya dapat mengelola kondisi yang dialami atau situasi yang menyebabkan munculnya stres serta adannya berbagai tuntutan meliputi tuntutan akademik. Berbeda dari hasil penelitian yang dilakukan peneliti dimana tingkat stres yang dialami responden yaitu lebih banyak mengalami stres sedang. ${ }^{27}$

Berdasarkan hasil penelitian, ditemukan banyaknya remaja yang mengalami stres sedang. Hal ini dapat dikarenakan adanya perbedaan lingkungan seperti teman baru, dikarenakan siswa remaja kelas X SMA kota Pontianak berasal dari sekolah yang berbeda saat duduk di bangku sekolah menengah pertama. Stres dapat terjadi dikarenakan adanya konflik dengan teman di sekolah maupun dengan keluarga di rumah. Stres bisa terjadi dikarenakan tekanan dalam belajar ataupun tuntutan yang harus dilakukan, setiap anak memiliki tingkat pemahaman yang berbeda dalam memeahami sesuatu. Apabila emaja tidak bias mengelola koflik atau masalah yang dihadapi dapat menyebabkan remaja tersebut dapat mengalami stres.

\section{Kecerdasan Emosi Pada Remaja Sekolah Menengah Atas Negeri Di Kota Pontianak}

Hasil penelitian menunjukan bahwa jumlah responden yang memiliki kecerdasan emosi tinggi sebanyak 12,4\% dan kecerdasan emosi rendah sebanyak 12,7\%. Mayoritas kecerdasan emosi yang dimiliki responden yaitu kecerdasan emosi sedang sebanyak $4,9 \%$.

Perkembangan emosi yang dialami pada remaja menunjukkan adanya sifat yang sensitif dan reaktif terhadap kejadian yang dialaminya. Perkembangan kecerdasan emosi remaja sedang memasuki tahap adanya ketegangan emosi meningkat akibat adanya perubahan fisik yang dialami serta tekanan dari lingkungan sosial. ${ }^{28}$

Hasil penelitian yang dilakukan oleh Illahi,Neviyarni,Said \& Ardi didapatkan hasil kecerdasan emosi yang dimiliki remaja MAN 1 Tanah Datar secara garis besar berada dalam kategori kecerdasan emosi tinggi dengan presentase $48,31 \%$ dan presentase paling rendah pada kecerdasan emosi rendah dengan presentase $17,42 \% .^{12}$ 
Berdasarkan hasil peneltian, didapatkan kecerdasan emosi pada remaja rata - rata pada tingkat kecerdasan emosi sedang. Kecerdasan emosi ini dapat terjadi dikarenakan adanya respon yang kurang dalam aspek - aspek kecerdasan emosi meliputi aspek mengenali emosi, mengontrol diri, empati dan bersosialisasi. Kecerdasan emosi sedang ini dapat diartikan bahwa remaja belajar menjadi individu yang tdak mudah terbawa emosi terhadap masalah yang dihadapi, meskipun masih ada aspek - aspek yang masih belum bisa untuk mengatur emosi yang ada dalam dirinya.

\section{Perilaku Bullying Pada Remaja Sekolah Menengah Atas Negeri Di Kota Pontianak}

Hasil penelitian menunjukan bahwa jumlah responden yang pernah melakukan bullying lebih banyak daripada yang tidak pernah melakukan bullying. Responden yang pernah melakukan bullying sebanyak $95,5 \%$ sedangkan responden yang tidak pernah melakukan bullying terdapat 4,5\% .

Perilaku bullying dapat terjadi dikarenakan proses sosialiasi yang tidak sempurna dari lingkungan rumah maupun lingkungan luar. Perilaku bullying dapat disebabkan adanya faktor dari lingkungan keluarga, mengikuti teman sebaya dan media massa. ${ }^{17}$

Hasil penelitian yang dilakukan oleh Indriyani mengenai perilaku bullying pada siswa SMA Al-Azhar 3 Bandar lampung didapatkan hasil siswa yang melakukan bullying mencapai 99,54\%. Bentuk perilaku bullying yang dilakukan paling banyak adalah bullying verbal. Remaja perempuan lebih banyak melakukan bullying relasional atau mengabaikan sedangkan pada laki - laki paling banyak melakukan bullying verbal. Pada penelitian ini responden banyak yang melakukan bullying verbal daripada bullying fisik. $^{13}$

Mayoritas remaja pernah melakukan bullying. Bullying yang terjadi pada remaja dapat dikarenakan adanya masalah dari keluarga seperti contoh keluarga yang tidak harmonis, mengikuti perilaku teman sebaya maupun melakukan bullying karena pengaruh lingkungan. Tindakan yang dilakukan remaja yaitu seperti menggoda temannya mengenai hal - hal yang tidak disukai, mengatakan komentar kasar kepada orang lain, memaki kepada sesama kawan, mengolok terhadap penampilan temannya. Selama peneliti melakukan penelitian tidak terlihat seorang remaja yang melakukan bullying fisik terhadap temannya seperti menendang temannya tetapi peneliti melihat terdapat remaja melakukan bullying verbal seperti mengatai temannya maupun bullying relasional seperti membicarakan atau bergossip tentang temannya.

\section{Hubungan Tingkat Stres Dengan Perilaku Bullying Pada Remaja Sekolah Menengah Atas Di Kota Pontianak}

Hasil penelitian ini didapatkan bahwa dari hasil uji statistik spearman dengan total 354 responden menunjukan nilai $\mathrm{p}$ value sebesar 0,290 yang berarti $\mathrm{p}>0,05$. Dapat disimpulkan bahwa Ho diterima dimana tidak terdapat hubungan antara Tingkat Stres dengan Perilaku Bullying pada Remaja Sekolah Menengah Atas di Kota Pontianak.

Perilaku bullying di sekolah dapat terjadi di beberapa tempat disekolah, biasanya di kelas, kantin atau di toilet sekolah. Perilaku bullying disekolah dapat dilakukan teman sekelas ataupun kakak kelas. Perilaku bullying ini dapat meresahkan siswa remaja yang sedang berada di sekolah. Perilaku bullying di sekolah dapat meliputi mengancam teman, mengolok-ngolok, dan memukul hingga keinginan pembully dipenuhi. Perilaku bullying sendiri merupakan tindakan berbahaya dan dapat menimbulkan dampak traumatik pada anak remaja yang dapat mempengaruhi dalam melanjutkan tahap perkembangan kedepannya. ${ }^{31}$ 
Hasil penelitian yang dilakukan oleh Utomo yang melakukan penelitian menggunakan wawancara dan observasi pada korban bullying didapatkan hasil yaitu korban bullying dituntut dapat beradaptasi dengan kondisi dan situasi yang tidak diinginkan dan tidak menyenangkan yang dialaminya. Efek dari terjadinya bullying apabila tidak diatasi dapat menyebabkan timbulnya stres, depresi, emosi dan korban bullying dapat terkena masalah psikologis. Salah satu tindakan yang dapat menangani stres yaitu dengan adanya strategi koping yang baik pada seorang individu. ${ }^{32}$

Tidak adanya hubungan antara tingkat stres dan bullying dapat dikarenakan tidak ada perbedaan pada remaja yang mengalami stres ringan maupun stres berat, remaja sama - sama pernah melakukan bullying. dari semua remaja yang mengalami stress ringan hanya 1 orang yang tidak pernah melakukan bullying begitu juga remaja yang mengalami stres berat hanya 1 orang yang tidak pernah melakukan bullying. remaja yang dapat mengontrol stres tidak semuanya dapat mengontrol diri terhadap ucapan maupun tindakan yang dilakukan.

\section{Hubungan Kecerdasan Emosi Dengan Perilaku Bullying Pada Remaja Sekolah Menengah Atas Di Kota Pontianak}

Hasil penelitian ini didapatkan bahwa dari hasil uji statistik spearman dengan total 354 responden menunjukan nilai $\mathrm{p}$ value sebesar 0,627 yang berarti $p>0,05$. Dapat disimpulkan bahwa Ho diterima dimana tidak terdapat hubungan antara Tingkat Stres dengan Perilaku Bullying pada Remaja Sekolah Menengah Atas di Kota Pontianak.

Individu yang mudah dikuasi oleh emosi negatif, dimana tidak adanya kemampuan individu dalam mengendalikan perasaan emosi atau kecerdasan emosi yang muncul dari dalam dirinya dapat menyebabkan remaja mudah melakukan perilaku bullying. ${ }^{14}$
Hasil penelitian yang diteliti oleh Swadnyana dan Tobing didapatakan hasil bahwa semakin tinggi kecerdasan emosi maka tingkat agrsifitas pada seseorang semakin rendah. Hasil dari penelitian ini tentang hubungan antara agresivitas dan kecerdasan emosional meskipun nilainya kecil tetapi dapat diyakini sebagai hubungan fungsional. Perilaku agresifitas merupakan perilaku akibat dari ketidakmampuan seseorang bertahan dan mendapat pengaruh negatif dari luar yang cenderung lakukan tindakan yang negatif atau melakukan kenakalan remaja. ${ }^{29}$

Berdasarkan hasil penelitian yang dilakukan oleh Nugraha,Dharmayana dan Sinthia mengenai hubungan antara kecerdasan emosi dengan perilaku bullying pada siswa SMK kelas X didapatkan hasil bahwa terdapat hubungan negatif yang signifikan anatara kecerdaan emosi dengan perilaku bullying. Tingkat kecerdasan emosi pada siswa SMK Kelas X termasuk golongan tinggi sedangkan tingkat perilaku bullying siswa SMK kelas $\mathrm{X}$ tergolong rendah. Semakin rendah perilaku bullying semakin tinggi kecerdasan emosi.Sebaliknya semakin tinggi perilaku bullying maka semakin rendah kecerdasan emosi pada seseorang. ${ }^{21}$

Remaja yang memiliki kecerdasan emosi yang tinggi, dapat membuat individu tidak hanya mampu mengontrol emosi tetapi juga dapat melakuakan apa yang seharusnya dilakukan oleh remaja sehingga dapat menghadapi dan menyelesaikan masalah yang dihadapi tanpa perlu marah ataupun merugikan orang lain. Tidak adanya hubungan antara kecerdasan emosi dapat dikarenakan tidak ada perbedaan yang memiliki tingkat kecedasan yang tinggi maupun rendah, remaja sama - sama pernah melakukan bullying. berdasarkan pegamatan peneliti, saat penelitian berlangsung, terdapat remaja yang melakukan bullying tetapi ia termasuk orang yang santai, tidak termasuk orang yang meledak - ledak. Individu 
tersebut menganggap bullying verbal yang ia lontarkan sebagai candaan.

\section{SIMPULAN SARAN}

Dari hasil penelitian yang telah dilakukan dapat disimpulkan bahwa karakteristik jenis kelamin yang terbanyak adalah perempuan sebesar 58,8\%, karakteristikk suku terbanyak adalah Melayu sebesar 48,0\%, karakteristik agama yang terbanyak adalah Islam sebesar 83,3\%. Tingkat stres yang paling banyak dialami responden yaitu stres sedang sebesar $85,0 \%$. Kecerdasan emosi yang dimiliki responden adalah kecerdasan emosi sedang sebesar 74,9\%. Hampir semua responden pernah melakukan perilaku bullying yaitu sebesar 95,5\%. Hasil analisis uji statistik didapatkan hasil bahwa tidak terdapat hubungan antara tingkat stres dan kecerdasan emosi dengan perilaku bullying pada remaja di Kota Pontianak. Artinya semakin ringan tingkat stres atau semakin tinggi kecerdasan emosi, tidak menutup kemungkinan seseorang melakukan bullying.

Saran teoritis dari penlitian ini diharapkan dapat menambah sumber referensi bagi penelitian selanjutnya mengenai data tingkat stres, kecerdaan emosi dan perilaku bullying pada remaja di Kota Pontianak.

Saran praktis bagi keperawatan diharapkan dapat menambah referensi pada bidang keperawatan jiwa dan keperawatan anak sebagai dasar dilakukannya intervensi yang tepat menangani stres dan perilaku bullying serta meningkatkan kecerdasan emosi. Saran praktis bagi institusi Diharapkan hasil penelitian ini dapat dijadikan landasan teori pembelajaran atau acuan penelitian lanjutan mengenai stres dan kecerdasan emosi serta perilaku bullying yang terjadi pada remaja.Saran praktis bagi sekolah diharapkan dapat menjadi masukan dengan adanya Unit Kesehatan Jiwa Sekolah yang dapat membantu para siswa dapat mengkonsulkan masalah kejiwaannya.

\section{REKOMENDASI}

Bagi penelitian selanjutnya dapat meneliti tentang penelitian kualitatif terhadap kejadian perilaku bullying yang sangat tinggi terjadi. Penelitian selanjutnya juga dapat memberikan intervensi dalam menangani stres yang dialami remaja dan meningkatkan kecerdasan emosi pada remaja.

\section{DAFTAR PUSTAKA}

1. Amalia, Emmy., Nurbaiti, Lina., Affarah, Wahyu Sulistya., Kadriyan, Hamsu. (2019). Skrining Dan Edukasi Pencegahan Bullying Pada Siswa SMA Negeri Di Kota Mataram..Jurnal Pengabdian Magister Pendidikan IPA, 1(2): 30-35.

2. Aprilistyawati, A. (2016). Keperawatan Psikiatri dan Kesehatan Jiwa.. Cetakan Pertama. Yogyakarta: Penerbit Kyta.

3. Awang, Azarudin., Mat, Azman Che., Mahmud, Wahairi. (2018). Kesepaduan Budaya Melayu Dalam Kehidupan Komuniti Cina Muslim Di Negeri Terengganu. Jurnal Kemanusiaan, 16(1): $7-11$.

4. Badan Pusat Satistik. (2010). Hasil Sensus Penduduk 2010. Diperoleh tanggal 1 Maret 2019 dari https://www.bps.go.id.

5. Badan Pusat Statistik. (2015). Hasil Survei Penduduk Antar Sensus 2015. Diperoleh tanggal 28 Januari 2019 dari https://www.bps.go.id.

6. Barseli, Mufadhal., Ifdil., Nikmarijal. (2017). Konsep Stres Akademik Siswa. Jurnal Konseling dan Pendidian, 5(3).

7. Batubara, J. (2010). Adolescent Development (Perkembangan Remaja). Jakarta: Sari Pediatric, 2(1), 22-29.

8. Data Statistik Kependudukan Provinsi Kalimantan Barat. (2018). Jumlah 
Penduduk Menurut Agama Semester 2 Tahun 2018. Diunduh dari https://dukcapil.kalbarprov.go.id.

9. Eviani,Herlin.,Ariati,Jati. (2014). The Relationship Between Coping Stress And Bullying In The Students Of SMK Muhammadiyah Of Kudus. Jurnal UNDIP, 3(4): 1-10.

10. Haba, John. (2012). Etnisitas, Hubungan Sosial dan Konflik Di Kalimantan Barat. Jurnal Masyarakat \& Budaya, 14(1): $31-51$.

11. Herawati, Anna Ayu. (2014). Hubungan Antara Kecerdasan Emosional Dengan Perilku Agresif Siswa Kelas X TM (Teknik Mesin) SMKN 2 Kota Bengkulu.Jurnal Universitas Bengkulu.

12. Illahi, Ulya., S.,Neviyarni., Said, Azrul., Ardi, Zadrian. (2018). Hubungan antara Kecerdasan Emosi dengan Perilaku Agresif Remaja dan Implikasinya dalam Bimbingan dan Konseling.Jurnal Indonesian Institute for Counceling, Education and Therapy (IICET).

13. Indriyani, Sisca. (2019). Analisis Perilaku Bullying Siswa Sekolah Menengah Atas Al-Azhar 3 Bandar Lmapung Tahun Ajaran 2018/2019. Universitas Lampung.

14. Jayanti, Winda Putri., Indrawati, Endang Sri. (2018). Hubungan Antara Kecerdasan Emosional Dengan Perilaku Bullying Pada Siswa Kelas XI SMK X Semarang. Universitas Diponegoro.

15. Kemenkes RI. (2013). Riset Kesehatan Dasar; RISKESDAS. Jakarta : Balitbang Kemenkes RI.

16. Kemenkes RI. (2014). Pusat Data dan Informasi. Jakarta : Kemenkes RI.

17. Lestari, Sri., Yusmasyah., Mayasari, Shinta.(2018). Bentuk Dan Faktor Penyebab Perilaku Bullying. Jurnal ALIBKIN, 6(2).

18. Nasrani, Lusia., Purnawati, Susy. (2016). Perbedaan Antara Laki - Laki Dan Perempuan Pada Peserta Yoga Di Kota
Denpasar. Jurnal Medika Udayana, 4(12).

19. Novianty, Alvi. (2016). Pengaruh Pola Asuh Otoriter Terhadap Kecerdasan Emosi Pada Remaja Madya. Jurnal Ilmiah Psikologi, 9 (1) : 17-25.

20. Novitasari, Yuni., Yusuf, Syamsu., Ilfiandra. (2017). Perbandingan Tingkat Spiritualitas Remaja Berdasarkan Gender dan Jurusan. Indonesian Journal of Educational Counseling, 1(2): 163 178.

21. Nugraha, Arif Budi., Dhamayana, I Wayan., Sinthia, Rita. (2019). Hubungan Antara Kecerdasan Emosi Dengan Perilaku Bullying. Jurnal Consilia, 2(1): $66-74$.

22. Nuraini, Q. (2018). Pengaruh Kecerdasan Emosional dan Efikasi Diri Terhadap Stress Akademik siswa Full Day School SMPIT Insan Permata Malang. Universitas Islam Negeri Maulana Malik Ibrahim Malang.

23. Poltekkes Depkes Jakarta. (2010). Kesehatan Remaja: Problem dan Solusinya. Jakarta : Salemba Medika.

24. Potter, P. A., dan Perry, A. J. (2010). Buku Ajar Fundamental Keperawatan Konsep, Proses, dan Praktik. Edisi 7. Jakarta : EGC.

25. Putri, Ayu Tria Kartika. (2018). Hubungan Pola Asuh Orang Tua Dan Penggunaan Media Sosial Dengan Perilaku Bullying Di Sekolah Pada Remaja .Universitas Airlangga.

26. Setiawan, Hari Harjanto. (2018). Peran Pekerja Sosial Di Sekolah Dalam Menangani Perundungan. Jurnal Sosio Informa, 4(1): 328 - 347.

27. Suci, R.N. (2016). Hubungan Stres Akademik Dengan Prestasi Belajar Pada Siswa SMAN 1 Sawahlunto. Universitas Andalas.

28. Supriadi, Dede., Yudiernawati, Atti., Rosdiana, Yanti. (2017). Hubungan Kecerdsan Emosional dengan 
Perkembangan Sosial pada Remaja di SMP Wahid Hasyim Malang. Jurnal Nursing News, 2(3).

29. Swadnyana, I Putu Bagus., Tobing, David Hizkia.(2019). Hubungan Antara Kecerdasan Emosional Dan Agresivitas Pada Remaja Madya Di SMA Dwijendra Denpasar. Jurnal Psikologi Udayana, 6(2): $1125-1134$.

30. Tempo. (2018). Hari Anak Nasional, KPAI Catat Kasus Bullying Paling Banyak, diakses pada tanggal 1 Maret 2017 dari https://nasional.tempo.co/read/1109584/ hari-anak-nasional-kpai-catat-kasusbullying-paling-banyak

31. Tristani, Rischa Pramudia ., Wardani, Silvia Yula. (2016). Perilaku Bullying Di Sekolah. Jurnal Bimbingan Dan Konseling, 1(1): $82-91$.

32. Utomo, Tri. (2016). Strategi Coping Korban Bullying Verbal Pada Siswa Kelas XI Di SMA N 11 Yogyakarta. Jurnal Riset Mahasiswa Bimbingan Dan Konseling, 5(12): $590-602$.

33. Wewengkang, Destareni Belda., Moordiningsih. (2016). Studi Fenomologi Konteks Budaya Jawa Dan Pengaruh Islam: Situasi Psikologis Keluarga Dalam Membangun Empati Pada Remaja. Jurnal Indigenous, 1(1): 1 -11 .

34. Yuliana, Siti., Hidayati, Eni. (2015). Pengaruh Terapi Musik Penurunan Tingkat Stres Pada Remaja Di Yayasan Panti Asuhan Kyai Ageng Majapahit Semarang. University Research Colluqium, 208 - 212.

35. Yusriadi. (2018). Indentitas Dayak dan Melayu Di Kalimantan Barat. Jurnal Handep, 1(2): 1 - 16. 